\title{
The Impact of Parental Separation and Divorce on the Health Status of Children, and the Ways to Improve it
}

\section{Motti Haimi ${ }^{1,2,3 *}$ and Aaron Lerner ${ }^{2,4}$}

${ }^{1}$ Clalit Health Services, Haifa district, Israel

${ }^{2}$ Rappaport Faculty of Medicine, Technion, Technological institute of Israel, Haifa, Israel

${ }^{3}$ The Center for evaluation of health promotion interventions, School of public Health, Haifa University, Haifa, Israel

${ }^{4}$ Pediatric Gastroenterology and Nutrition Unit, Carmel Medical Center, Haifa, Israel

\begin{abstract}
The divorce rate rose steadily in recent years, becoming a significant social problem. Many studies showed that the divorce has negative impact on children, but there are many different interpretations of the consequences of this situation on children's lives.

There is no doubt that children are being affected by the sudden change in their familial environment as well as by additional influences that accompany the divorce process. It is well recognized that the divorce process affects the mental state of the children, including development of behavioral problems, negative self-concept, social problems, and difficulties in relationships with the parents. Among these children there is a higher frequency of depression, violence, learning and social deterioration, and high risk for suicidal attempts. Research in recent years had shown that the divorce process apparently affects also the state of physical illness in children.

Based on clinical and empirical studies in recent years, for most children, the traditional visiting arrangements are out of date, unnecessarily restrictive, and do not meet the interests of the children themselves. There are many advantages for children in separation and divorce situations when the children's living arrangements allow the caring fathers to be actively involved in the life of their children, when there are broad visiting arrangements or even shared custody arrangements.

In these situations, there is a significant reduction in the negative aspects of the divorce process and there is an objectively beneficial effect on children's adjustment, which is also reflected from the experience of the children themselves.

We describe the situation in Israel and recommend the appropriate management in these cases according to our experience and recently studies.
\end{abstract}

Keywords: Divorce; Children; Living arrangements; Father's role; Health state

\section{Introduction}

Although the widespread belief regarding the family life that the marriage should be a lifetime commitment, the divorce rate in the world is growing. Among industrialized countries, the highest divorce rate is in the United States, where about half of all first marriages end in divorce and more than a million children experience their parents' divorce each year.

In Israel the divorce rate is also high. The number of divorcing families in Israel is rising steadily in recent years and become a significant social problem in the $21^{\text {st }}$ century. During 1986 and 1995 , the number of divorces in Israel rose in $86 \%$. During 1990 and 2000 this number rose in $61 \%$. With such a large amount of children and adolescents who experience the divorce, it is important to understand how this process affects them $[1,2]$.

During the ' 80 s and ' 90 s many studies in various fields investigated the question whether there is a negative effect of this process on children. Although most studies indicated that divorce has negative impact on children, there are many different interpretations about the consequences of this situation on children, especially about the intensity of the effect, whether the negative impact is arising from the divorce itself or from the process, and whether this process can actually sometimes be good for the kids in some situations.

In addition to the negative effects of the divorce itself on children, we should consider also the negative effects on children resulting from the conflict between the parents, which is frequently ugly and bitter. There is no doubt that considerable casualties of this struggle are the children themselves.

\section{The impact of divorce process on mental illness and modes of behavior in children}

In 1991, Amato and Keith [3] have examined the results of 92 studies that included 13000 children who experienced the divorce. The results were that the condition of these children was on average less well than children of "regular" families. The children had more difficulties in school, more behavioral problems, more negative selfconcept, more social problems with their peers, and more difficulties getting along with their parents. More recent studies $[4,5]$ corroborated these findings.

However, Amato also emphasized in the study from 1994 [6] that the average differences between these groups do not indicate that all

${ }^{*}$ Corresponding author: Motti Haimi, Clalit Health Services, Haifa district, Israel, Tel: 97248351654; E-mail: morx@netvision.net.il

Received December 19, 2015; Accepted January 30, 2016; Published February 06, 2016

Citation: Haimi M, Lerner A (2016) The Impact of Parental Separation and Divorce on the Health Status of Children, and the Ways to Improve it. J Clin Med Genomics 4: 137. doi:10.4172/2472-128X.1000137

Copyright: $\odot 2016$ Haimi M, et al. This is an open-access article distributed unde the terms of the Creative Commons Attribution License, which permits unrestricted use, distribution, and reproduction in any medium, provided the original author and source are credited. 
children in families of divorce status were in worse condition than children of ordinary families. These results show that as a group, children from families experiencing divorce had more problems than children from normal families.

In her research in 1993, Hetherington's [7] reports that $90 \%$ of the adolescents in regular families were in the normal range in terms of having problems, while $10 \%$ had serious problems that required professional help. However, in families who experienced divorce-74\% of boys and $66 \%$ of the girls were in the normal range, while $26 \%$ of boys and $34 \%$ of the girls were in the "problematic" range. However, Amato [8] estimated that about $40 \%$ of the young adults of the divorced families -were in better condition than young people of the "regular" families. Additional studies $[5,9,10]$ listed several factors that may contribute to explain these differences:

- The parent's loss: the divorce process brings often lost contact with one of their parents. This loss is accompanied by loss of knowledge, skills and resources (financial, emotional) of the parent.

- Economic loss: Another result of the divorce is that children living in single-parent families - usually don't have the same resources as children in regular families.

- "Stress" - the divorce process is accompanied by many changes in daily life of children, like changing schools, the child care, the home place, etc. Children must also adapt to changes in relationships with friends and extended family. These changes create a more stressful environment for children.

- Reduced parental adaptation: coping of children in families depend on the mental mode of parents, and this is true also in families who have experienced divorce.

- The lack of ability or compliance (COMPETENCE) of the parents: much of what happens to children is influenced by the parents' skills to help them develop. The competence of the parents after divorce has a significant impact on children.

- Exposure to conflict between parents: this conflict exists in every family, especially in families who have experienced divorce. The level of conflict to which children are exposed has a fatal impact on the well-being of children.

Behavioral problems and depression: Many studies conducted by Dr. Joan Kelly, on kids of divorced parents [10-23], revealed that as the conflict intensifies the likelihood of behavioral problems and depression among children rises. This applies both to the children of married parents (who are in conflict) and divorced parents. These effects were evident even in adulthood, so that adults, who reported marital conflict between parents, expressed significantly more behavioral problems and depression, than adults, who grew up as children of parents who relationships were good.

The nature and character of the conflict also had a direct effect on the child in the family: as the conflict was more focused on the child, so that the child is the object of the conflict, the greater the negative impact on the child was. In addition, as the conflict was more frequent and stronger in character and the degree of violence involved was higher - the risk of a negative impact on children increased.

However, parents who demonstrate good capacity (even if incomplete) in solving conflicts-reduce the level of stress and anxiety of the children. In a study [24] conducted on children under the age of 3 it was observed that families with two parents-functioned better when compared to children in single-parent families (with unmarried or divorced mothers) regarding cognitive and social abilities, and problematic behavior.

Criminal behavior, violence and impairment of masculine development: In their paper, Kalter et al. [25], described a clinical study, carried out during a period of 10 years, with approximately 600 children of divorced parents. It was found that boys to divorced parents, who remained in the custody of their mother, had impaired masculine development, due to lack of a male figure. Also found for boys, a sort of criminal behavior tendency and difficulty to control impulses.

The Researchers determined that, boys need positive identification with their fathers in order to control their behavior. When the contact with the father was minimal, it explained the criminal behavior of the boys. In his article, Pfiffner et al. [26] reported that in families where the father's presence was maintained, less anti-social symptoms appeared among parents and children. DeGarmo and Forgatch [27] also examined the variables that affect criminal behavior among children of divorced mothers who stayed at school, and reported a decrease in criminality after intervention.

A new study from Slovakia $[27,28]$ examined the incidence of alcoholism in adolescents in families of divorced parents. It showed that the divorce had an effect of on adolescents' alcoholism mainly in the last month, and that positive involvement of the father after divorce - was a protective factor relating to alcoholism in families who have experienced divorce. Wolchik et al. [29] claim that compared to teens of un-divorced parents, teenagers of divorced parents- have a higher risk of developing mental disorders, to drop out of school or get pregnant.

Educational and social decline: Amato and Keith [3] indicated that for children who have experienced more difficulties in the divorce had more behavioral problems. More recent studies have shown that when children have a close relationship with their father and the fathers are actively involved in their lives-it is related significantly to better adaptability and improved academic achievement in school age children, compared to children with less involved fathers. Higher paternal involvement in school is associated with better academic function and better behavior, including higher scores, fewer absences and a positive attitude to school, compared to young children whose fathers were less involved [30].

Suicides: In a study from Denmark [31], the researchers evaluated the risk factors for suicide among young people, attributed to familial and socioeconomic factors. Among other parental factors that were related to increased risk of suicide among young people-was also the parents' divorce. Other studies investigated whether there are differences in prevalence and suicidal attempts among boys and girls of divorced parents. One study [32] reported a higher incidence of depression, suicidal attempts and higher risk of suicide among girls of divorced parents compared to boys of divorced parents, whereas another study [33] reported a higher rate of suicide ideation among boys of divorced parents.

Child abuse: A study from Kuwait [34] among 4467 students checked the presence of events of childhood abuse. There was a definite connection between child abuse and parental divorce.

Regarding the abuse of children in situations where a father figure was missing regardless to divorce, a big research on behalf of the Pentagon [35] found that children of parents serving in the military were prone to abuse and neglect from their mothers when their fathers 
were at war in Iraq or Afghanistan. According to the study, it was found that when fathers were stationed during war far from home, the mothers confessed that they gave inappropriate treatment to their children 3 times more than compared to the period fathers were at home. During these periods, when the fathers were not at home, mothers who were home alone, have neglected their children four times more than usual and abused them physically twice more than usual.

The importance of the contact with the father: Studies in psychology during the past 25 years indicate that the father importance in the life of his children is no less than that of the mother. In the article [12] of Kelly, she emphasizes that in the past, divorce cases were mostly in extreme cases of abandonment, alcoholism, mental illness, neglect etc. In these circumstances, there was no expectation that the father will maintain continuous contact with the children. This tradition has expanded into the 1970s, but when the divorce cases increased and the circumstances changed, more studies were made while making reexamination of the fathers' role. Many studies have highlighted the lack of the children's satisfaction, of the restricted visits with their fathers. The children who had good connection with their fathers felt seeing their dad so little was intolerable, and the younger boys felt a sense of dread that their father abandoned them.

In a study done in 2007 [36] among young adults, it was observed that as these people stayed longer with their fathers during their childhood after the divorce, so their relationship with their fathers were better at reaching maturity period as is their general medical condition. Bad relations between children and fathers - predicted worse health in adulthood.

Parental alienation syndrome: Parental alienation syndrome is a childhood disorder that appears almost exclusively in contexts of struggles over the child. Dr. Richard Gardner set the term "parental alienation syndrome", a phenomenon that arises primarily in the context of custody battles, in which the child participates in the allout campaign against either of his parents in which its content has no foundation in reality. In this disorder, one parent (the parent alienating) makes defamation campaign against the other parent (the alienated parent, victim).

In this disorder, brain-wash exists not only by one parent against the other parent, but also created a situation where the child makes claims against the alienated parent to contribute to the alienating parent's defamation [37-39]. Despite controversy over Gardner [39] many articles were written on this topic, including in Israel $[40,41]$.

False allegations of sexual abuse: This phenomenon of false allegations of sexual and physical abuse of children made by their parents against their other parent in divorced families -is growing in recent years. Some scholars see this as an epidemic that is spreading [42-44]. Cooke and Cooke [45] noted in their study that clinical and statistical findings indicate that there is a high probability that charges are likely to be false accusations, in the circumstances of custody and divorce battles. In most cases the charges are of the mother towards her husband or former husband during or after divorce. There is no doubt that these allegations - have an impact on the deepening conflict between parents and as a result they have an effect on children who are exposed to conflicts and tension between parents.

The effect of the divorce process on different children in the same family: A study from 2003 [46] found that different siblings experience the divorce process in the same way as regards to the education level of children and their chance to get divorced in the future. However, this is only one factor among many in the child's future impact.
Various studies [47] checked also if it possible to relate the psychopathology and a tendency to delinquency among teenagers in situations of divorce to a genetic tendency and not to the divorce process itself. This hypothesis was tested in the families that adopted children as compared to families with biological children who have experienced divorce. The similar results which were obtained in the 2 types of families demonstrated that the experience of the divorce process is the one that affects juvenile delinquency during adolescence and not the genetic tendency in those families.

\section{The influence of the divorce process on physical illness in children}

Although the main effects of the divorce process are evident in the behavioral and emotional field, physical morbidity of the children was also described in these situations. For example, a study from Taiwan [48] found a clear link between parental divorce and children's daily headache ( $\mathrm{CDH}-$ chronic daily headache). Various studies have described increased prevalence of ADHD (Attention Deficit \& hyperactivity Disorder) in children in situations of divorce and Abuse [49], and increased prevalence of hyperactivity and attention deficit disorder in families with increased risk (divorce, low socioeconomic status, and large family size) [50]. A large research from Korea [51] among 2673 students described that children and adolescents have an increased risk of developing ADHD in families experiencing situations of separation and divorce. An increased risk of hyperactivity and behavior problems among preschoolers was described in families that have experienced separation or intense family conflicts [52].

Another study from France [53] examined the relationship between adverse family environment during childhood and self-perceived health in adulthood. It was found that exposure to separation and divorce in childhood was associated with worse health perception in older age. The study referred to the mental health as well as to the physical status. It was found that this parameter was influenced by the relationship between parent and child, and whether that person was a witness to violence between the parents during childhood. A study from Spain [54] that examined the quality of life (QOF) as perceived by children themselves-reported higher QOF in children to married parents than those of divorced parents. Children who reported on a conflict between the parents after divorce had the lowest QOF.

\section{Living arrangements of children after separation and divorce and their effects on children's adjustment}

When parents separate, children typically enter into new living arrangements with each parent, according to a frame determined by the parents themselves, or in accordance with the recommendations and decisions of lawyers, therapists, or the courts. Most of these decisions resulted in the fact that since the 60's children spend most of their time with one parent and only limited time with the other parent (the "visitor") [55].

Most of these decisions were based on traditional beliefs and opinions in relation to the parental visit arrangements after the separation. Based on the traditional beliefs that mothers stayed home to care for the children, while fathers worked as the main salary earning, it was assumed that mothers will serve as the main care taker after separation, while the fathers will only "visit" their children in a way that reflects their "minor" role in raising children [55]. Most of the guidelines regarding visitation and custody, designed as a uniform prescription suitable for everyone ("one-size-fits-all"), in which the children live half the time with the custodial parent, and several individual days 
are served for the non-custodial parent, who is usually the father. This parenting program was simple to implement, not demanding legal or psychological analysis, reflected the non-established belief that children will be harmed if they have more than one home [55].

In recent years, along with the empowerment of women and their struggle for equality, the voice of many fathers is heard, wishing to take part in their children's lives. Despite many new studies showing the important contribution of both the father and the mother to the children's adaptation [56], although many countries have adopted constitutions in the 1980s and early 1990s to encourage frequent visits and allow joint physical custody (shared physical custody) as a common parental option, despite the large numbers of women who work outside home, despite the fact that men want to take much responsibility for the treatment of their children during marriage [53-57]-living arrangements for children after a divorce remain stable for the last 35 years and the legal and constitutional traditions that have been imprinted were hard to change.

In the early 1990 s to about $20 \%$ of the parents around the world was a constitutional joint custody (legal custody). Studies performed in Arizona, California and Massachusetts have shown that when the law was changed and allowed joint legal custody, the rate of parents who have carried out a joint legal custody grew up to $50-90 \%[11,58$ 60]. Joint legal custody enables both parents to participate in important decisions concerning their children (e.g., decisions related to health, education, daycare, etc.), while in individual custody -one parent makes all the decisions and don't have to consult or notify the other parent. The "terminology" of joint custody meant to illustrate that the children are staying significant periods with both parents, although not necessarily in a 50-50 Division [55,58-61].

Despite the relative improvement over the last years in visiting arrangements with the fathers, there is still an unexplained resistance to such arrangements among mothers and some professionals who claim, without any evidence to be based on, that kids can't go to school from different residential places. Although joint custody rate still remains low, $35 \%$ to $60 \%$ of children have at least some weekly visits with their fathers and usually even lodging during the week $[58,60]$.

Although the encouraging changes, as a result of divorce research that emphasizes the importance of ongoing contact with the father to the well-being of the child, only a minority of children have satisfying weekly contact with the non-custodial parent (usually the father) after separation. This is despite the data showing that the traditional arrangements lead to decreased contact and closeness between the children and the non-custodial parent [55,62-66].

\section{Reducing the negative effects on children}

In their article, Brinig and Buckley [67] claimed that like everything else in divorce, child custody struggle, often looks like a game of everything or nothing, where one spouse loses and one win. In joint custody, both parents have access to their children and share the responsibility and shared commitments to their growth. Joint custody reduces the pain of divorce for children. For a child, a sole custody, can look like the death of the non-custodial parent, and in many ways, it is. Although joint custody is not a continuation of the parents' marriage, its eases the difficulties of the child and helps him in this circumstances. Turkat describes [68] the problems existing with visiting arrangements. In her book she emphasize that wide visiting arrangements with the non-custodial parent, is important for the parent and child.

\section{The children's conception about living arrangements}

Earlier studies found that most children reported the loss of the non-custodial parent as the most negative aspect of divorce and that they were disappointed from the visiting arrangements. They described their father as peripheral in terms of closeness and emotional support $[62,69,70]$.

Recent studies reported that half of children and adolescents have stated that they want a closer relationship with their fathers, and onethird of them wanted this relationship to be longer.

In studies from New Zealand, only $2 \%$ of children wanted less contact with their father, particularly when the father was tough, angry or not interested [71,72]. Among college students who have experienced their parents' divorce 11 years earlier, more than half said they wanted to spend more time with their fathers. $70 \%$ of these young adults reported the arrangement of equal times was the best solution. Among those who lived in a shared custody 93\% expressed satisfaction and believed that the arrangement was the best for them [73,74].

In several studies $[5,70,75,76]$ bad relationships were observed between children who have reached the age of young- adults and their fathers, especially lack of affection and trust, compared to young-adults in families where the parents are married. However, in cases where the adolescents had a good relationship with their father at time of breakup and frequent contacts with the fathers, there was no difference between these young adults and adolescents in non- divorced families [77]. For most children to families undergoing separation or divorce -their thoughts regarding the living arrangements and their flexibility, will be taken into account by the parents [15,71,77-79]. Adolescents tended to see their living arrangements as satisfying when they could see the noncustodial parent whenever desired [79].

\section{The effect of living arrangements on children's adjustment}

In the article of Bauserman [80], the author states that children in joint custody are adapting better than children who grow up with a single custodial parent and the same as children to married parents. Separate comparisons were made about adaptation, family relationships, selfconfidence, emotional and behavioral adjustment and adaptation to a divorce. The results matched the assumption that shared custody can benefit children, probably because they help to maintain an ongoing positive relationship with both parents.

The risk of adaptation problems, social problems and academic problems is 2 times higher in children of divorced parents, compared to families where the parents are married $[5,14,81,82]$.

Factors that reduce the risk of these issues include: warm and competent parents, lack of depression and other psychological disorders among parents, low conflict, and certain aspects of living arrangements after separation [20].

There is an extensive literature on the relationship between the frequency of contact with fathers and children's adjustment. The frequency itself wasn't a good predictor of child outcomes, since some of the fathers had different parenting quality, and the length of the visits was not taken under consideration. Not only the frequency of visits is important, but also the quality of the relationship between parent and child, the type of parenthood provided by fathers, and the length of the contact. All of these parameters are related to the adjustment of children [55]. In situations of low conflict, and in the case of boys and younger children, frequent and regular contact with fathers was linked to better adaptability of the children $[73,83,84]$. The children 
did not benefit from frequent contacts with the non-custodial parent when he had a mental illness or when he was a drug addict or had poor parenting habits, exactly in the same way as children's adjustment negatively affected when the custodial parent suffers from similar problems $[9,14,70,82,85-87]$.

When children have a close relationship with their father and the fathers are actively involved in their lives, it is associated with a significantly better adaptability and improved academic achievement in school aged children, compared to children with less involved fathers. Active involvement in these cases includes help in homework, emotional support, and authoritative parenting (setting boundaries appropriately, non-compulsive discipline, and setting rules of behavior).

Reduced parental involvement after the divorce is related to more behavioral problems, especially among boys, but when both mothers and fathers are actively involved and provide authoritative parenting including controlling the behavior of children, teenage boys didn't have more criminal behavior than children in families with married parents $[70,81]$. Higher degrees of the father's involvement are associated with better adaptive behavior skills and better communication (socialization) skills in children at a young age, compared to cases where there is less involvement of the fathers [87].

Adolescents whose fathers were involved and supported the children regularly were significantly more likely to finish high school and enter college, compared to those whose fathers weren't involved [88]. In order to maintain the connections created with both parents prior to separation, infants and toddlers - should be able to continue frequent contacts, including overnight stays, with the non-custodial parent, and to avoid prolonged separations from either one of their parents $[22,89$ 91]. In families experiencing separation and divorce without a history of violence, children aged 4-6 years, who stayed overnight one or more times with their fathers, had better psychological and social adjustment compared to children who didn't have this opportunity $[55,90]$.

\section{Sole physical custody versus joint physical custody}

Early studies reported better adaptation of children of joint physical custody compared to children who were in sole custody and better satisfaction of the children in relation to joint custody. However, samples were relatively small [55]. Meta-analysis of 33 studies [55] comparing joint custody to maternal sole custody has shown that children that in joint custody arrangements have adapted better examining many measures of adaptation: general adaptation, behavioral adaptation, emotional adaptation, self-esteem, family relationships, and adapting to the divorced situation.

Two other studies found similarly that shared physical custody is more useful for children and adolescents compared to maternal custody in many individual measures when the conflict was low, but these benefits decreased in cases of high levels of conflict [92].

In a recently published large consensus report [93] of 110 researches and practitioners it was clearly stated that, in normal circumstances, the evidence supports shared residential arrangements for children under 4 years of age whose parents live apart from each other.

The report quotes the studies that identify overnights as a protective factor associated with increased father commitment to child rearing and reduced incidence of father drop-out. In the absence of studies that demonstrate any net risk of overnights, the writers ask the policymakers to recognize that depriving young children of overnights with their fathers could compromise the quality of developing father-child relationships. They conclude that there is no sufficient evidence to support postponing the introduction of regular and frequent involvement, including overnights, of both parents with their babies and toddlers.

\section{The situation in Israel}

In 2005 the Schnitt's Committee was appointed by the Minister of Justice, to examine and make recommendations regarding the legal aspects of parental responsibility in situations of divorce.

The committee has released an interim report for public comments in April 2008, and a completed report in September 2011.

The Committee's recommendations include a legislation proposal to regulate parental responsibility for implementing the rights of the child and ensure they favor when the parents are married and when they get divorced. It was suggested to establish in law the relationship between parents and children on parental responsibility for the implementing of children's rights. The parents and the State are required to put "the best interests of the child" to be the first consideration in any action they take. The committee argued that there is no place to set a general rule as the one that exists today, in which children under the age of 6 years are automatically staying in their mother custody. Unfortunately, for various reasons, mostly political, the Schnitt's Committee conclusions were not yet implemented.

\section{Conclusions}

An extensive empirical literature exists concerning the identification of factors that promote good adaptation and recovery or otherwise increase the risk for children of divorce. Among these, there are factors related to the living arrangements of the children, especially the restrictions that exist in terms of traditional arrangements in families with supporting fathers.

In General, the empirical literature shows many advantages for children including psychological adaptation and better behavioral and academic achievement when living arrangements of the children allow the supporting and loving fathers to be involved actively in the life of their children on a weekly basis and regularly. Furthermore, the children themselves want more contact with the non-custodial parent as compared to what typically was agreed between parents or by the courts and many of them prefer the concept of shared physical custody.

These children and adolescents living in the arrangement of joint custody feel loved and satisfied, report less feeling of loss and don't look at life through the lens of their parents' divorce, compared to children living in sole custody with their mothers. Israel also began recently, finally, like other enlightened countries, step towards a sane and fairer future concerning the recommendations in situations of separation and divorce. It must be remembered that the principle of "best interests of the child" is the basic principle and should be the primary consideration, and should not let extraneous considerations arising from power struggles, to influence the decisions about the fate of the children.

We call the policymakers to accept and implement the Schnitt's Committee conclusions which bring a proper solution to the issue of children in situations of parental separation and divorce.

\section{References}

1. Bronshtein E (2002) A guide to social workers in the parent-child meeting centers. Ministry of welfare p: 217.

2. (2016) Annual statistic book, Central Bureau of Statistics (Israel).

3. Amato PR, Keith B (1991) Parental divorce and the well-being of children: a meta-analysis. Psychol Bull 110: 26-46. 
Citation: Haimi M, Lerner A (2016) The Impact of Parental Separation and Divorce on the Health Status of Children, and the Ways to Improve it. J Clin Med Genomics 4: 137. doi:10.4172/2472-128X.1000137

Page 6 of 7

4. Amato PR (2001) Children of divorce in the 1990s: an update of the Amato and Keith (1991) meta-analysis. Fam Psychol 15: 355-370.

5. Amato $P(2000)$ The consequences of divorce for adults and children. Journal of Marriage and Family 62: 1269-1287.

6. Amato PR (1994) Life-span adjustment of children to their parents' divorce. Future Child 4: 143-164.

7. Rende RD, Plomin R, Reiss D, Hetherington EM (1993) Genetic and environmental influences on depressive symptomatology in adolescence: individual differences and extreme scores. J Child Psychol Psychiatry 34: 138798.

8. Amato P, Gilbreth J (1999) Nonresident fathers and children's well-being: A meta-analysis. Journal of Marriage and the Family 61: 557-573.

9. Amato PR, Fowler F (2002) Parenting practices, child adjustment, and family diversity. Journal of Marriage and Family 64: 703-716.

10. Kelly J, Emery R (2003) Children's adjustment following divorce: Risk and resilience perspectives. Family Relations 52: 352-362.

11. Kelly J (1993) Developing and implementing post-divorce parenting plans: Does the forum make a difference? In: Bray J, Depner C (eds.), Nonresidential parenting: New vistas in family living. Newbury Park, CA: Sage. 136-155.

12. Kelly JB (1994) The determination of child custody. The Future of Children Children and Divorce 4: 121-242.

13. Kelly JB (1996) A decade of divorce mediation research: Some answers and questions. Family and Conciliation Courts Review 34: 373-385.

14. Kelly JB (2000) Children's adjustment in conflicted marriage and divorce: a decade review of research. Am Acad Child Adolesc Psychiatry 39: 963-973.

15. Kelly JB (2002) Psychological and legal interventions for parents and children in custody and access disputes: Current research and practice. Virginia Journal of Social Policy and Law 10: 129-163.

16. Kelly JB (2003) Parents with enduring child disputes: Multiple pathways to enduring disputes. Journal of Family Studies 9: 37-50.

17. Kelly JB (2003) Parents with enduring child disputes: Focused interventions with parents in enduring disputes. Journal of Family Studies 9: 51-62.

18. Kelly JB (2004) Family mediation research: Is there support for the field? Conflict. Resolution Quarterly 3-35.

19. Kelly JB (2005) Developing beneficial parenting plan models for children following separation and divorce. Journal of the American Academy of Matrimonial Lawyers 19: 101-118.

20. Kelly J, Emery R (2003) Children's adjustment following divorce: Risk and resilience perspectives. Family Relations 52: 352-362.

21. Kelly JB, Johnston JR (2001) The alienated child: A reformulation of parental alienation syndrome. Family Courts Review 39: 249-266.

22. Kelly J, Lamb M (2000) Using child development research to make appropriate custody and access decisions. Family and Conciliation Courts Review 38: 297 311.

23. Kelly JB, Lamb ME (2003) Developmental issues in relocation cases involving young children: when, whether, and how? Fam Psychol 17: 193-205.

24. Clarke-Stewart KA, Vandell DL, McCartney K, Owen MT, Booth C (2000) Effects of parental separation and divorce on very young children. Fam Psychol 14: $304-326$

25. Kalter N, Alpern D, Spence R, Plunkett JW (1984) Locus of control in children of divorce. Pers Assess 48: 410-414.

26. Pfiffner LJ, McBurnett K, Rathouz PJ (2001) Father absence and familial antisocial characteristics. Abnorm Child Psychol 29: 357-367.

27. DeGarmo DS, Forgatch MS (2005) Early development of delinquency within divorced families: evaluating a randomized preventive intervention trial. Dev Sci 8: 229-39.

28. Tomcikova Z, Madarasova Geckova A, Reijneveld SA, van Dijk JP (2011) Parental divorce, adolescents' feelings toward parents and drunkenness in adolescents. Eur Addict Res 17: 113-118.

29. Wolchik SA, Sandler IN, Millsap RE, Plummer BA, Greene SM, et al. (2002) Sixyear follow-up of preventive interventions for children of divorce: a randomized controlled trial. AMA 288: 1874-1881.
30. Nord C, Brimhall D, West J (1997) Fathers' involvement in their children's schools.1997; Washington, DC: National Center for Education Statistics, U.S Department of Education.

31. Agerbo E, Nordentoft M, Mortensen PB (2002) Familial, psychiatric, and socioeconomic risk factors for suicide in young people: nested case-contro study. BMJ 325: 74.

32. Lizardi D, Thompson RG, Keyes K, Hasin D (2010) The role of depression in the differential effect of childhood parental divorce on male and female adult offspring suicide attempt risk. Nerv Ment Dis 198: 687-690.

33. Fuller-Thomson E, Dalton AD (2011) Suicidal ideation among individuals whose parents have divorced: findings from a representative Canadian community survey.Psychiatry Res 187: 150-5.

34. Al-Fayez GA, Ohaeri JU, Gado OM (2012) Prevalence of physical psychological, and sexual abuse among a nationwide sample of Arab high school students: association with family characteristics, anxiety, depression, self-esteem, and quality of life. Soc Psychiatry Psychiatr Epidemiol 47: 53-66.

35. Gibbs DA, Martin SL, Clinton-Sherrod M, Hardison Walters JL, et al. (2010) Child maltreatment within military families. In: Wadsworth SMD, Riggs D (eds.), Risk and Resilience in U.S. Military Families. New York, NY: Springer Science+Business Media, LLC.

36. Fabricius WV, Luecken LJ (2007) Postdivorce living arrangements, parent conflict, and long-term physical health correlates for children of divorce. Fam Psychol 21: 195-205

37. Gotlib D (2004) Parental alienation syndrome. Medicine and law, Psychology and law section 31

38. Dunne J, Hedrick M (1994) The Parental Alienation Syndrome: An Analysis of Sixteen Selected Cases. Journal of Divorce and Remarriage 21: 21-38.

39. Gardner RA (2002) Denial of the parental alienation syndrome also harms women. American Journal of Family Therapy 30: 191-202.

40. Bergamn Z, Vitztum A (1995) Child abduction by a parent and parent alienation syndrome. Sihot 9

41. Levita Z (1997) Contact refusal and conflict in parent-child relations in situations of separation and divorce 2 .

42. Gardner RA (1992) The Parental Alienation Syndrome. Crosskill, NJ: Creative Therapeutics.

43. Faller KC, Froning ML, Lipovsky J (1991) The parent-child interview: use in evaluating child allegations of sexual abuse by the parent. Am J Orthopsychiatry 61: 552-557.

44. Rogers ML (2002) Delusional disorder and the evaluation of mistaken sexua allegation in child cases. Am J of Forensic Psychology 10: 47-69.

45. Cooke G, Cooke M (1991) Dealing with sexual abuse allegations in the context of custody evaluation. Am J of Forensic Psychology 9: 56-67.

46. Wolfinger NH, Kowaleski-Jones L, Smith KR (2003) Double impact: what sibling data can tell us about the long-term negative effects of parental divorce. Soc Biol 50: 58-76

47. Burt SA, Barnes AR, McGue M, lacono WG (2008) Parental divorce and adolescent delinquency: ruling out the impact of common genes. Dev Psychol 44: 1668-1677.

48. Juang KD, Wang SJ, Fuh JL, Lu SR, Chen YS (2004) Association between adolescent chronic daily headache and childhood adversity: a communitybased study. Cephalalgia 24: 54-59.

49. Cohen AJ, Adler N, Kaplan SJ, Pelcovitz D, Mandel FS (2002) Interactiona effects of marital status and physical abuse on adolescent psychopathology. Child Abuse Negl 26: 277-288.

50. Larsson H, Dilshad R, Lichtenstein P, Barker ED (2011) Developmenta trajectories of DSM-IV symptoms of attention-deficit/hyperactivity disorder: genetic effects, family risk and associated psychopathology. Child Psycho Psychiatry 52: 954-963.

51. Kim HW, Cho SC, Kim BN, Kim JW, Shin MS, et al. (2009) Perinatal and familia risk factors are associated with full syndrome and subthreshold attention-deficit hyperactivity disorder in a korean community sample. Psychiatry Investig 6: 278-85. 
Citation: Haimi M, Lerner A (2016) The Impact of Parental Separation and Divorce on the Health Status of Children, and the Ways to Improve it. J Clin Med Genomics 4: 137. doi:10.4172/2472-128X.1000137

52. Stadelmann S, Perren S, Groeben M, von Klitzing K (2010) Parental separation and children's behavioral/emotional problems: the impact of parental representations and family conflict. Fam Process 49: 92-108.

53. Roustit C, Campoy E, Renahy E, King G, Parizot I, et al. (2011) Family socia environment in childhood and self-rated health in young adulthood. BMC Public Health 11: 949 .

54. Orgilés M, Samper MA (2011) [Impact of divorce on quality of life in children aged 8-12 years in the province of Alicante (Spain)]. Gac Sanit 25: 490-494.

55. Kelly JB (2007) Children's living arrangements following separation and divorce: insights from empirical and clinical research. Fam Process 46: 35-52.

56. Pleck, JH, Masciadrelli BP (2004) Paternal involvement by U.S. residentia fathers: Levels, sources, and consequences. 2004. In: Lamb ME (Ed.), the role of the father in child development (4th edn.), New York, 222-271.

57. Lamb ME (2004) The role of the father in child development. New York: Wiley.

58. Braver SL, O'Connell D (1998) Divorced dads: Shattering the myths. New York: Tarcher/ Putnam.

59. Braver SL, Ellman IM, Fabricius WV (2003) Relocation of children after divorce and children's best interests: new evidence and legal considerations. Fam Psychol 17: 206-219.

60. Maccoby E, Mnookin R (1992) Dividing the child. Cambridge, MA: Harvard University Press.

61. Seltzer JA (1998) Father by law: effects of joint legal custody on nonresident fathers' involvement with children. Demography 35: 135-146.

62. Amato $P$ (1987) Family processes in one-parent, stepparent, and intact families: The child's point of view. Journal of Marriage and Family 49: 327-337.

63. Furstenberg F, Nord CW, Peterson JL, Zill N (1983) The life course of children of divorce: Marital disruption and parental contact. American Sociological Review 8: 656-668.

64. Hetherington EM, Cox M, Cox R (1985) Long-term effects of divorce and remarriage on the adjustment of children. Am Acad Child Psychiatry 24: 518530

65. Seltzer J (1991) Relationships between fathers and children who live apart: The father's role after separation. Journal of Marriage and the Family 53: 79-101.

66. Smyth B (2005) Time to rethink time? The experience of time with children after divorce. Family Matters 71: 4-10.

67. Brinig MF, Buckley FH (1998) Joint Custody: Bonding and Monitoring Theories. Indiana Law Journal. 73: 393

68. Turkat ID (1994) Child Visitation Interference in Divorce. Clinical Psychology Review 14: 737-742.

69. Wallerstein J, Kelly J (1980) Surviving the breakup: How children and parents cope with divorce. New York: Basic Books.

70. Hetherington EM (1999) Should we stay together for the sake of the children? 1999. In E.M. Hetherington (Ed.), Coping with divorce, single parenting, and remarriage. Mahwah, NJ: Erlbaum. 93-116.

71. Smith AB, Gollop MM (2001) What children think separating parents should know. New Zealand Journal of Psychology 30: 23-31.

72. Smith AB, Taylor NJ, Tapp P (2003) Rethinking children's involvement in decision making after parental separation. Childhood 10: 210-216.

73. Fabricius WV, Braver SF, Deneau KA (2003) Divorced parents' financial support of their children's college expenses. Family Court Review 41: 224-241.
74. Laumann-Billings L, Emery RE (2000) Distress among young adults from divorced families. Fam Psychol 14: 671-687.

75. Ahrons CR, Tanner JL (2003) Adult children and their fathers: Relationship changes 20 years after parental divorce. Family Relations 52: 340-351.

76. Booth A, Amato PR (2009) Parental pre divorce relations and offspring postdivorce wellbeing. Journal of Marriage and Family 63: 197-212.

77. King V (2002) Parental divorce and interpersonal trust in adult offspring. Journal of Marriage and Family 64: 642-656.

78. Dunn J, Davies LC, O'Connor TG, Sturgess W (2001) Family lives and friendships: the perspectives of children in step-, single-parent, and nonstep families. Fam Psychol 15: 272-287.

79. Parkinson P, Cashmore J, Single J (2005) Adolescents' views on the fairness of parenting and financial arrangements after separation. Family Court Review 43: 429-444.

80. Bauserman R (2002) Child adjustment in joint-custody versus sole-custody arrangements: a meta-analytic review. Fam Psychol 16: 91-102.

81. Simons RL, Lin KH, Gordon LC, Conger RD, Lorenz FO (1999) Explaining the higher incidence of adjustment problems among children of divorce compared with those in two-parent families. Journal of Marriage and the Family 61: 10201033

82. Emery RE (1999) Marriage, divorce, and children's adjustment (2nd edn.) Thousand Oaks, CA: Sage.

83. Amato P, Rezac S (1994) Contact with residential parents, interparental conflict, and children's behavior. Journal of Family Issues 15: 191-207.

84. Stewart AJ, Copeland AP, Chester NA, Malley JE, Barenbaum NB (1997) Separating together: How divorce transforms families. New York: Guilford Press.

85. Johnston JR, Roseby V (1997) In the name of the child: A developmental approach to understanding and helping children of conflict and violent divorce. New York: Free Press.

86. Kline M, Johnston J, Tschann J (1991) The long shadow of marital conflict: A model of children's post-divorce adjustment. Journal of Marriage and the Family. 53: 297-309.

87. Pruett MK, Williams TY, Insabella G, Little TD (2003) Family and legal indicators of child adjustment to divorce among families with young children. Fam Psychol 17: $169-180$

88. Menning CL (2002) Absent parents are more than money: The joint effects of activities and financial support on youths' educational attainment. Journal of Family Issues 23: 648-671.

89. Pruett MK (2005) Applications of attachment theory and child development research to young children's overnights in separated and divorced families. Overnights and Young Children. Essays from the Family Court Review pp: 5-12.

90. Pruett MK, Ebling R, Insabella G (2004) Critical aspects of parenting plans for young children. Family Court Review 42: 39-59.

91. Warshak RA (2002) Who will be there when I cry in the night? Family Court Review 40: 208-219.

92. Lee MY (2002) A model of children's post-divorce behavioral adjustment in maternal and dual-residence arrangements. Journal of Family Issues 23: 672 697.

93. Warshak RA (2014) Social Science and Parenting Plans for Young Children: A Consensus Report; Psychology, Public Policy, and Law 20: 46-67. 